\title{
木忉の煻化及び濃鹽酸の工業的使用法
}

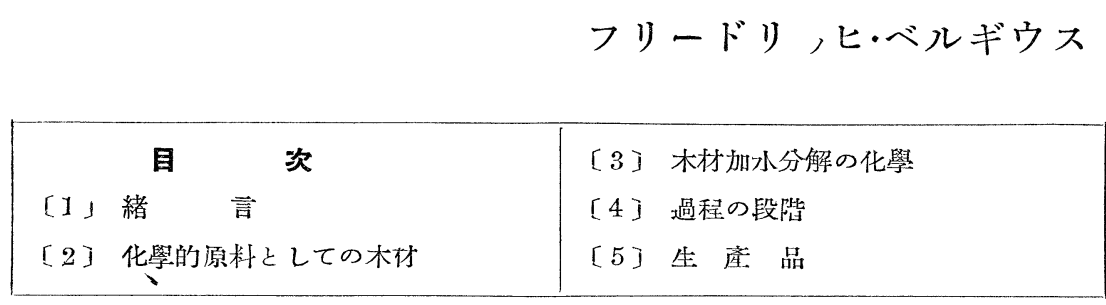

[1]綨

$\overrightarrow{\overrightarrow{\vec{n}}}$

ナポレ゙ン戰争時代に於て英國か歐玔諸展を封鎖し，諸生產物の大陸への輸入を好害するの に成功した時，打鎖されたる諸國の抆術家及ひ化學者達は甜杂榶工業を發達させ，此の重要食 料品を自由に供給した。斯くして急迫せる必要により種々の經嚌的及ひ工業的成功か齎らされ た。諸國の政府は再ひ外界より歐川に諸生產物の轉入か可能となつた，次の自由貿易時化に於 て此の新工業を維持し，獎勵するととを助成した。

過去數年間飞於て生活飞必要なる原料を國內に於て生產するといふ問題は，各國の住意を未

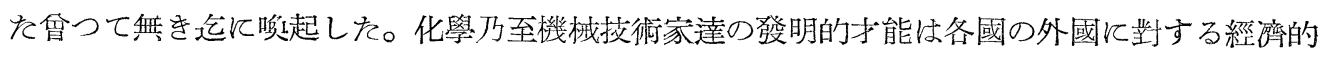
從屬性を削减し，且つ以前をては签大しなけれはならなかつた諸生產物を，出來るたけ多く國 內て製造する孚に用ひられる樣になつた。此の目的の妥に工業的な必要の妥に探用される新製 法か發明され，獎勵されねはならなくなつた。

此の傾向は非常飞批判されたか，論坫は結局，此の諸活動か國際商業及ひ自由貿易を益从妨 害してるるといふ結論に達した。然しなから批炋家達は，工業的に進步した諸國は永い閒完成

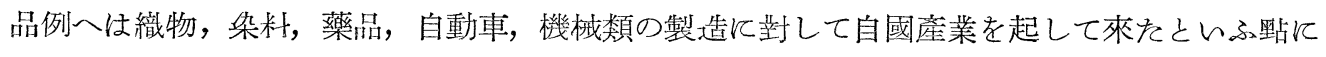
留意すへきてある。工業的燋步してるる諸國は殆と全部技術的に改良された產物を製造し， 從つて，保護關稅を設けると至つた。過去 20 年間に於てトイツは最も重要なる原料品の製造 といふ問題にたつさはつて來た。そして私は，私の協力者達と共㵝去 25 年間か〉る問題の 解仭江從事して來を。私達は水素㬄加法により石炭からカソリン及ひ其の他の伷を作る方法を 發明したか，此の方法は今や，トイツ及び英國に於て近代生活に必須なる佾體燃料の製倦法と して廣く用ひられてるる。

天然夜體燃籵の供給か非常に减少してるるといふ間題は未た差迫つてはるないけれぞも，石 炭を石伷に變へるといふ吾くの努うは無駄てはなかつを。原伷の供給を受けない國，或は供給 を夌けても不充分な國々に於ける經齊界及ひ政佁界に於ては，此の石炭を石伷て變へる可能性 を非常飞尊重してるる。彼等は假へ生產費は相當額に上るけれとも，外國の供給眸らないと いふ事かもつと重要てあるといふ事をよく承知してるる。最初石炭は埶と動力の原泉として用 ひられたか，年かたつにつれて石炭は種々の化學製品の基本的原料としての重要性を增して 

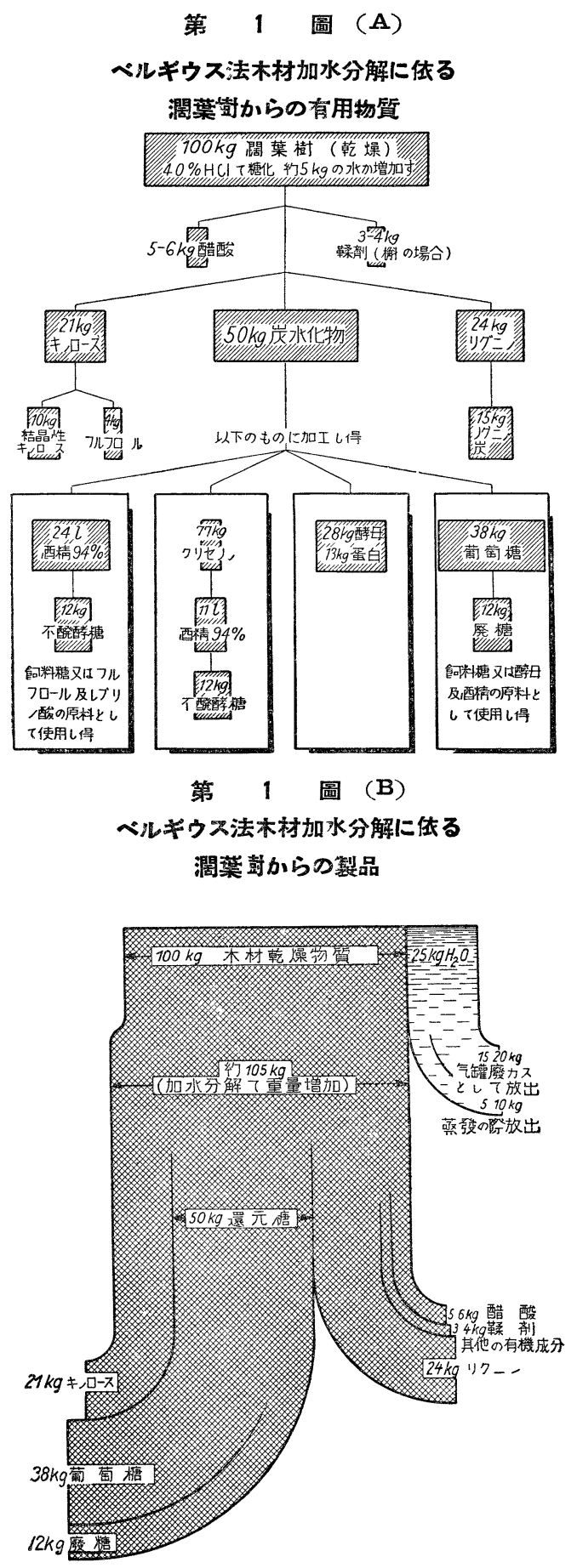

來た。石炭乾溜によりベンゾール，ナフタ リン及び染料，近代的合成藥品の基本的原 料をるコールタール製品類を造る事が出來 る。此の高溫度に於ける破壊的蒸溜は芳香 族化合物を生する。然るに低温度に於ける 水素添加法によればハイドロアロマティッ ク，或はアリファティクの炭化水素を製造 するととが出來，而して，石炭の分子構造 は生成物の中水常飞高度に保をれる。

\section{[2] 化學的原料としての木材}

石炭の母體をる木材は永年の間，主なる 建築材料として用ひられて來をが，最近に 至つて化學的原料として考慮されるに至 つ市。注意染く取扱はられつば木材の性質 はアリファティック化合物の製造飞適する。 木材を原料として使用する以前からの化學 的處理法に於ては木材の大部分注浪費さ れる。例へばパルプ工業に於ては 5 割以下 が役立たつのてあつて，殘りは失はれる。 木材乾溜によれば有用なる物質は 4 割以下 方製造されるに過ぎす，殘りは無水炭酸之 水の形て失はれる。樹脂及ひ鞣皮材料を探 取する諸工業儿於ては極少收量て滿足しな ければならない。而も木材の 9 割か燃料と して使用されるなけてある。

現世紀の始め飞米國飞於ては沸坫以上の 溫度の稀薄を酸の助け飞依つて, 琚屎から 醱睹性の砂糖を四收するととが試みられ， 木材からアルコールを製造する最初の專門 工場が 1910 年, サウス・カロライナ州の ジョージタウン市にエウィントムリンソン 會社によつて設立された。製材場の锯㡈は 稀硫酸て處理されそが，アルコールの㢆出量は理論上の豫想高より遙に少なかつた。同漾の木 材糖化の原理がドイツのショーラー氏飞依つて探用されれが，彼はより以上の產出量（理論上の 
第 2 圖 (A)

ヘルキュウス法加水分解による針葉樹よりの有用物質

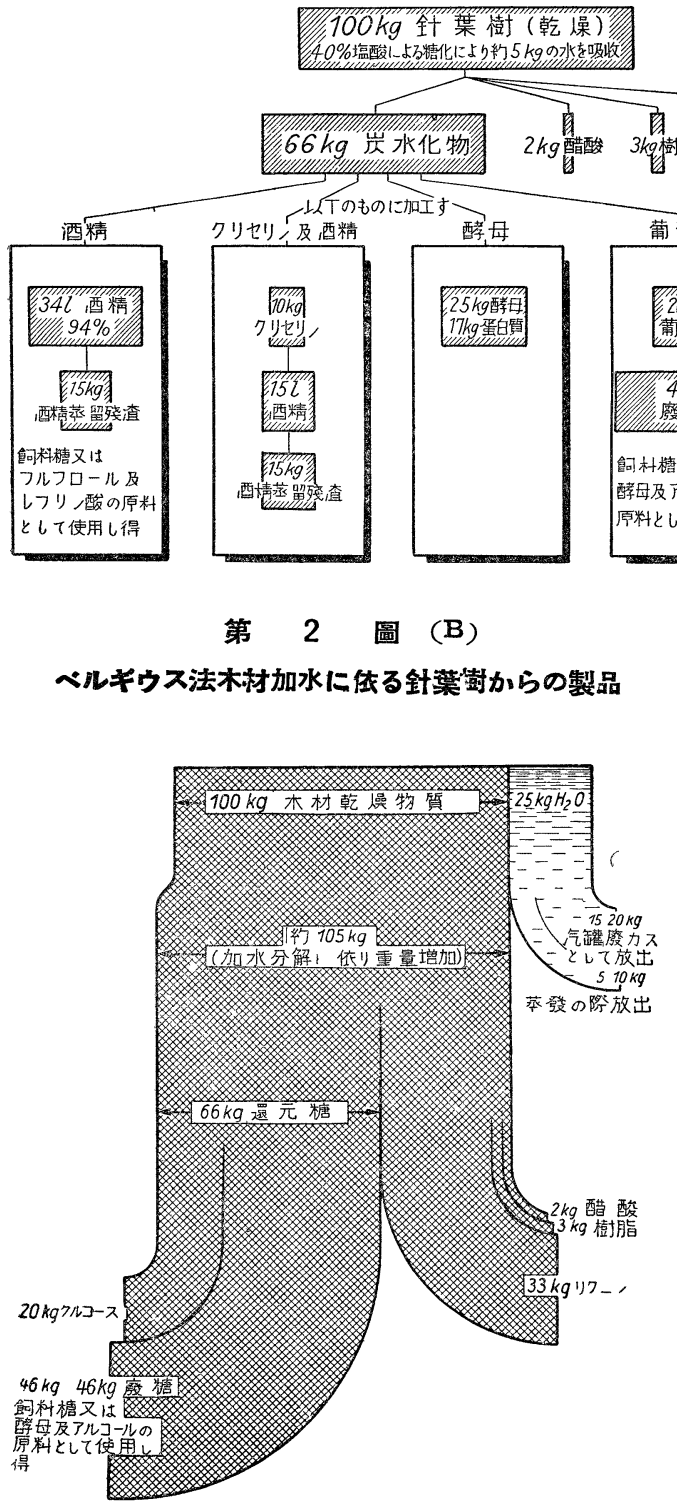
した。
豫想高の 60 ～70\% 位) を 得たが，然し醇㫴しな ければならない砂糖液 は $3 \%$ 以下の砂糖を 含有するに過ざかつ た。

若し濃監酸が普通の 温度飞於て纖維素を加 水分解する媒介として 用ひられるならば，遙 か纪良い結果分得られ る。ウィルステッター 及びチェッへマイスター爾氏は空缊で $40 \%$ の鹽酸に依り織維素が溶解されるととを發見

此の溶夜中に於て纖維素は數時間內に廢物 を出さないて葡萄榶に變はる。乙れと依つて 多し斯かる條件か揃へ代 100\% の理論的結果 を收めるととが出來るといふ事が制る。

1916 年にェリック・ヘッグルント氏と私は ウィルステッター，チェッヘマスター兩氏に より發表された反應を基礎として工業的方法 を發展せしめるととに着手した。明かに私達 はウィルステッター，チェッヘマイスター兩 氏が化學的實驗飞於てしたやうに，纖維素を 原料に使用することは出來なかつた。私達は 此の反應を木村或々゙屑に應用しなければな らなかつた。此の木屑は纖維素の外には主に ヘミ纖維素及びリグニンを含有してねる。リ グニンを除けば殆ど總べての木材の成分は濃鹽酸に溶解する。非常に多量の木忉が森の中て失 はれる。郎ち，木材の $50 \%$ 以下が材木として使はれ，殘りは失はれるか又は燃籵として使はれ る。まを多量の木材か製材或は同樣の仕事に於て浪費される。斯くして私達の木材加水分解法 の大量の原料は磨價て大手出來る。

最初私達は木材加水分解法の產物は炭水化物であり, それは大麥や王蜀㯟と同樣と糧秝とし 
て用ひられたり，また睽醅させる材料として用ひられると思つた。なほまた私達は此の產物は 最後に人類の俏費の秀に適當な形に變へられると信した。然し長年月を要して技術的に完全な 方法を考入出すととか出來るやうになつた。大林林や，木材屑を所有する國家は加水分解法に 依つて一定の食料原料手て入れるととか出來るといるととか明かてあつた。䐁は炭水化物類 を脂肪汇變へる。故飞，炭水化物，脂肪及び蛋白質類は木材砂糖夜か動物飞より消費されると

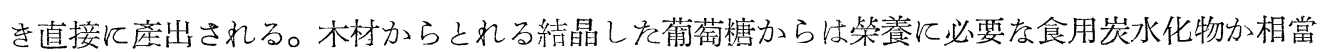
多量飞出來る。換言すれば木材の属から食物の基本要素類を實際的飞製造するととか出來る。 此の製造は森林資源を减らさないて行ふととか出來る。何故なら，製材から生する屑は木材加 水分解の原料を非常飞多量飞供給するととか出佲るからてある。

\section{[3] 木忉加水分解の化學}

木材加水分解の化學的反應は單純てあつて水 1 分子をセルローズ1分子に加へるをけてあ る。然しなから，此の反㷳を工場規模に於て實行するのは非常に困難てある。

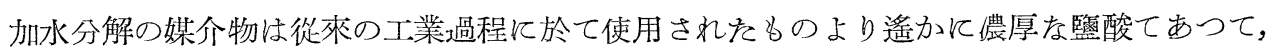
濃厚なる酸は實際に於て斯かる工業的裝置に適するあらゆる全屬を侵す。それ故に噟虭性酸に 堪へる裝置を設計し，組立てるととか必要てあつた。此の問題の解决に信賽するてとか出來る のは私の昔からの势力者, フリッッ・コ，ホ氏の精巧さを有する妥てある。現今使用されてる

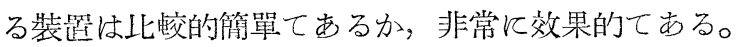

\section{[4]過程 の 段階}

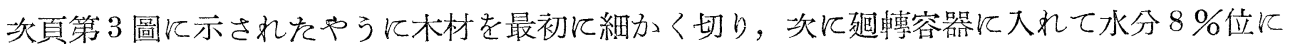

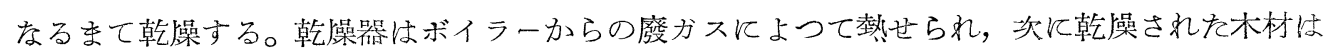
鐵の分解槽（ティフューリーヘ,テリー）の中て非常に儂厚な酸と接觸する。ハ,テリーの最後の部 分に入る新らしい濃厚な酸は，溶解性の成分を殆に゙抽出されれ木材々接觸する。八,テリーの 中て作用する間に此の酸は段及溶解性の木質を吸收し，最後に第一の槽の中て新しい木質と接 觸する。此の方法に依つて，加水分解された木材の極度に濃厚な溶夜办得られる。此の夜は約 $32 \%$ 容量の還元㜍の酸性溶夜てある。此の高い濃度は加水分解物から鹽酸を回收する次の如を

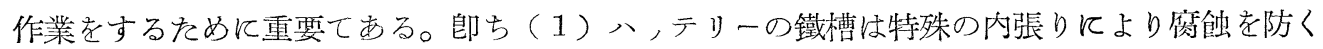
事か出來る，(2) 3 年間作業を續行してるるか，腐玲乃至漏損の微候は無かつたてと，（3）作 業方法も進展して，鐵槽飞溶夜を滿し又は空にしたりしても職工或は建築物に害を及政すやう な水發酸の遗漏は無かつをとと等てある。

此の作業をしてるる間に，木材の重量の2/3は酸により液體と化し，殘り垎はリクニンの形に 於て鐵槙內に㙛万。鹽酸を組織的に順序を逐つて先ひ取つて了へは，中性のリグニンは鐵慒の 底を開くと簡單に取り去るととか出來る。リクニンは燃料として使用する事か出來る。これは 全く灰を生しない多のて，粘結劑を使はないて煉り固めれは其のま〉純椊の木炭になる。次に 


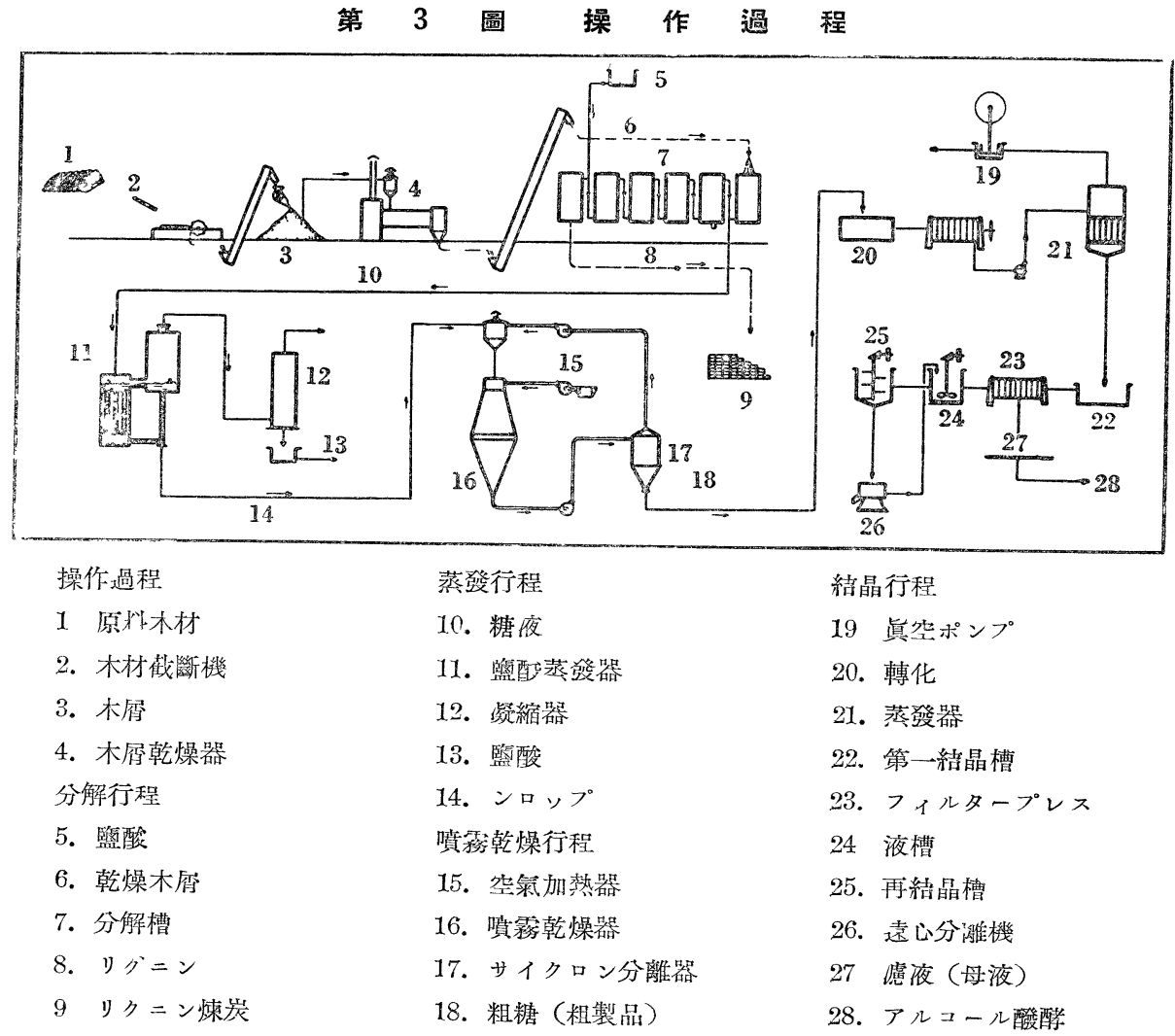

バッデリーから取つた液は約 $36 \mathrm{C}^{\circ}$ て真空蒸溜する。鹽酸は蒸發され，凝縮して酸の再生及び 再濃縮裝置に運ばれ，そこから又分解䏆に返る。鹽酸の蒸溜裝置が最後的に進步するまでには 永年か」り，それ以前には此の種蒸溜器には全く需要が無かつた。多くの蒸發器より成る耐酸 性の裝置は熱の良導性を持つ特殊の陶器材料から咸る多くのチューブて組立てられた。てれ等 のチューブの表面 $1 \mathrm{~m}^{2}$ からは $12 \mathrm{~kg} / \mathrm{hr}$ の酸が蒸發する。乙れは非常に良い成績と見做すべき である。

此の裝置を組立てる上に於ての主な問題は種々の陶器及び鐵の部分の熱膨張率の異るととか らくる危險な結果を避けるととてある。私達は今や，眞空狀態て覧酸を蒸溜し濃繀する裝置を 持つてみるが，此の蒸溜器は滿足な成績をあけて居る。郎ち熱渻費が極めて經齊的であり，大

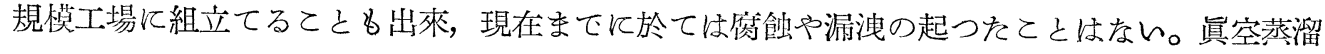

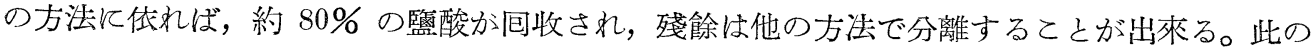
目的の営には特別の噴蓩乾燥器か用ひられ，微細な霧狀になつた濃厚な溶夜と接觸した熱氣か 鹽酸と水とを蒸發させる。出來上つれ固形物は 1〜2\% の鹽酸, 約 $8 \%$ の水分, $90 \%$ 糖分 を含み，てれはサイクロンにより探取され，最後に監酸の蒸気は凝繀され，洗抄され，酸は再 び循環される。 


\section{第 4 圖

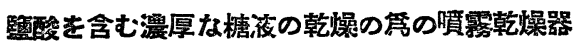

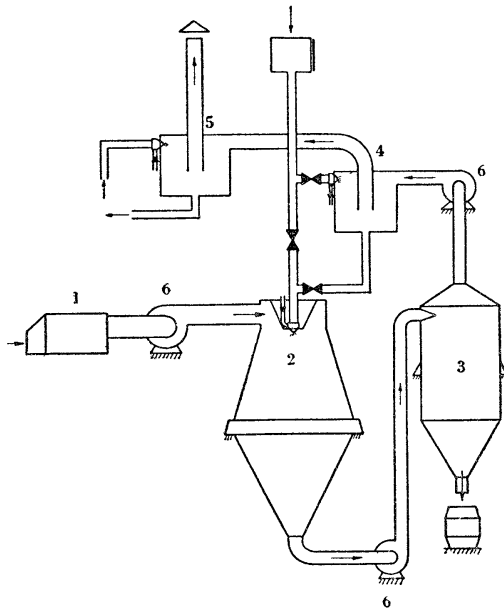

1. 筀氣加熱器

2. 噴霧款燥器

3. 遠心力依り颙懆された 粗粒を分離するサイクロン

4. 分離器, 糖夜て噴霧珗條する

5 分離器, 水て噴霧珗條する

6. 运風機

糖液は噴霧乾燥器 2 几入り厭摧空氣て賀霧され, 蓺空氣に依り蒸發される。乾燥室に入つたものは凡 て逘風器佂よりサイクロン 3 亿运られ, 此處て相粒 は擬集し抜き出されて下の槽一行く。微㹨な存游粒

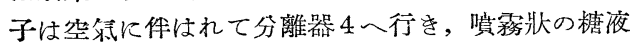
下依り珗條されて分離する。珗條使用された此の 糖液は再び糖液の主供給管飞合一する。 4 から出た 空氮は次の分離器 5 亿到り賃霧狀の水て再び珗條さ

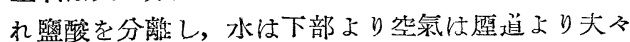
排出される。

\section{第 5 圖 \\ 管狀鹽酸䔲發器}

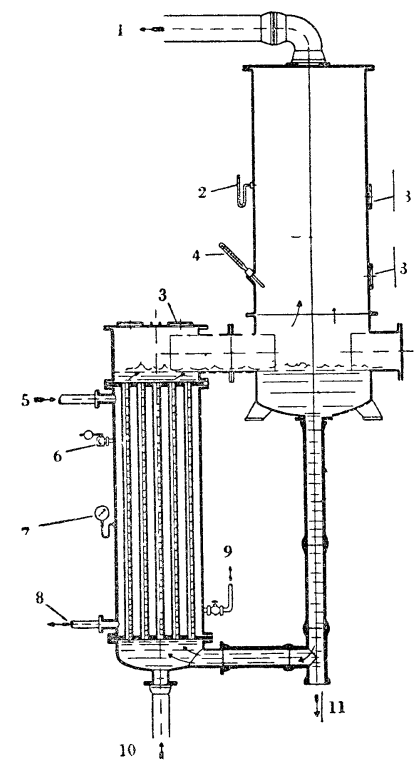

7 厭力計

8 凝縮小出口

9 排雨

10 溶夜大口

11 ンロップ

5 小蒸気入口

6 安全瓣

固形の加水分解生成物は原料木材の性質に より異るが，葡萄榶，マンノーズ，キシロー ズ，ガラクトーズ，果榶等を含有し，乙れ等は主にテトラメリック型をなしてわる。モノメ リック型からテトラメック型へのポリメリゼーションはバッテリーと噴霧乾燥器との間の過程 飞於て起てり，種々の糖分の全產出量は初めの乾燥木材の $60 \sim 66 \%$ 飞上る。

若し, 粗加水分解生戌物（偷 $1 \sim 2 \%$ 監酸を含んてるる）を其の 3 倍容積つ水て稀䆁し, $120^{\circ} \mathrm{C}$ に約牛時間熱すれば,テトラメリック型の煻穎は容易に且つ損夫なくモノメリック型と變はり，

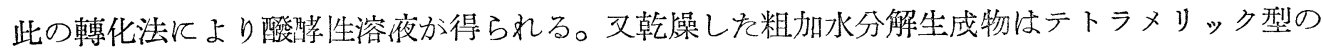
糖分類を含んてるるが，石灰て此の少量の酸を中和すれは橿柇として用ふるととか出來る。2

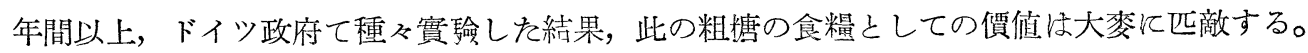
斯くして得られた糧秝は長期の貯藏飞而へる。此の粗糖は $20 \%$ 還元榶を含有する溶夜中に

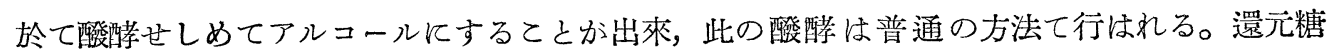


$100 \mathrm{~kg}$ から純度 $100 \%$ のアルコール約 507 (約 13 カロー)か取れる。換言すれは乾喿木質 1 英噸からはプルーフ190のアルコールか 85〜90 ガロン取れる。粗糖中のキシロースやカラク

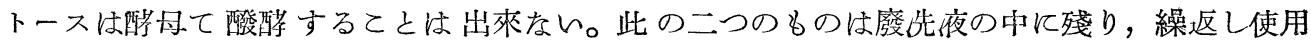
すれは段々に濃くなり，先夜は次に蒸發され，殘りは鑛酸を加へないて噴霧乾喿器の中て乾か されて安定な製品になる。此の製品は糧秝，其の他の品として使用される。

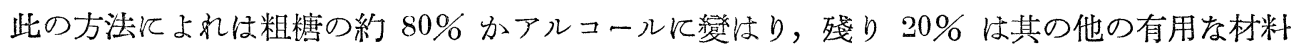

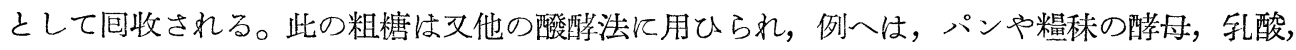

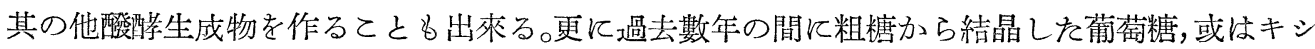
ロースを作るカ法も出來を。兩者のうち重要なのは結晶性葡萄糖て，てれは大量に俏費される。 此の轉化された粗榶の溶夜は中和され，濾過され，儂縮されてのち容易に結晶する。再結晶の 方法に上り白く，非常飞純椊者葡萄糖か得られる。

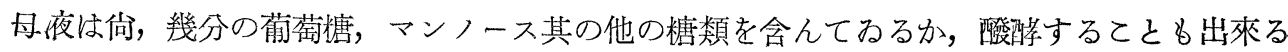
し，或は糧抹として用ひられる。此の方法に依れは糖分は全然損失かない。特殊な方法により キシローズも亦結晶の形て包收される。

此の方法の副產物の一つに醋酸かあるか，乙れは加水分解バ,テリーから出る溶夜の中に含 まれてるる。鹽酸から醋酸を分離する特殊な方法か案出された。此の方去飞依れば同時に水か ら鹽酸をガス狀て分離するてとか出來る。此の分離は非常に必要てある。何故ならリクニンを 先ひ出す時飞水分必必す幾分かは此のシステムの中に入つて行くか，てれは必す排除しなけれ ばならないものてあるからてある。

回收された醋酸の量は木材乾留法て得られる量と同してある。此處て回收される醋酸の量は 木材の乾留法て 得られる醋酸の重量と百分率飞於て符合する。リグニンの炭化法によれば木 炭とメタノールか出來る。斯くして私達の此の方法に依れは木材乾留の主要產物を產出するて とか出來るはかりてなく，木材乾留法に於て，通常ては無水炭酸や水の形て失れはる木材の $60 \%$ 汃今度壮糖分として回收出來る。

斯くして，此の方法の主なる特色は木材の屑の中に含まれる物質の殆ど總へてが，或一つの 形まをは其の他の形に於て,世界中何處に於ても需要のある, 或る有用なる生產物飞變へられる といふてとてある。 